\title{
Nexus Between Land Grabbing and Development: Perspective of Environmental Injustice in Ethiopia
}

\author{
Jemal Hussein Abdulle ${ }^{1, ~ *, ~ M u f e d e i ~ M o h a m m e d ~ K a s i m ² ~}$ \\ ${ }^{1}$ College of Social Sciences, Oda Bultum University, Chiro, Ethiopia \\ ${ }^{2}$ College of Natural Resource and Environmental Science, Oda Bultum University, Chiro, Ethiopia
}

Email address:

Jemalhussein7@gmail.com (J. H. Abdulle)

*Corresponding author

\section{To cite this article:}

Jemal Hussein Abdulle, Mufedei Mohammed Kasim. Nexus Between Land Grabbing and Development: Perspective of Environmental Injustice in Ethiopia. American Journal of Environmental Protection. Special Issue: Enhancing Natural Resource Conservation for Sustainable Development. Vol. 8, No. 6, 2019, pp. 115-120. doi: 10.11648/j.ajep.20190806.12

Received: August 19, 2019; Accepted: October 15, 2019; Published: December 2, 2019

\begin{abstract}
This paper explores the overall relationship between land grabbing and development from the perspective of environmental injustice in Ethiopia. The study principally relied on analysis and reflection of secondary sources. Hitherto, much scholarly discourse has tried to seek remedy for the challenges of land grabbing from political aspects. However, this article attempted to open up a new vista of environmental stewardship from the view point of ethical philosophy. Therefore, we try to explore how land grabbing, as one instance of environmental injustice, has negatively affected the development of societies in Ethiopia. The problem of land grabbing is reality in many parts of Ethiopia like Gambella, Oromia and Benishangul-Gumuz regions. For instance, the Elfora Agro-Industries owner has also evicted poor societies from their land without proper compensation. The integration of Addis Ababa, the capital city of Ethiopia, with the surrounding area is one form of land grabbing which impose negative impacts on the genuine development of local communities in Ethiopia. As a result, we suggest that inspiring marginalized communities to participate in environmental decision making is very important issue. For instance, Indian Conglomerate Karuturi Company had acquired so many hectares of land by displacing local communities without paying proper compensation for the local societies in the above mentioned regions of Ethiopia.
\end{abstract}

Keywords: Development, Environment, Environmental Injustice, Integrated Master Plan, Land Grabbing

\section{Introduction}

The problem of environmental injustice and lack of genuine human development are major problems confronting developing countries [1-3]. Likewise, there exist many of environmental injustice problems in Ethiopia which pose a threat to human development [4]. The poor local societies are displaced from their land without getting proper compensation in Ethiopia [5]. To support this view, Oakland Institute [1] explores that in many African countries including Ethiopia, Serra Leone, and Liberia there is land market (land grabbing) that transferred the land to foreign investors in the name of improving the countries investment policies. In addition, International Financial Corporation (IFC) and the Foreign Investment Advisory Service (FIAS) have provided technical assistance and advisory services to lease their land [5].

Furthermore, Rahmato argues that many countries in Africa including Ethiopia have given millions of hectares of farmland to investors in the name of large-scale investment, and they believe this will provide opportunities for rapid agrarian development that can play significant role in tackling rural poverty in the continent [6]. In connection with this, he stated the land is owned by the government in Ethiopia. So, government authorities can give away land to investors without the consent of farmers and making environmental impact assessment [7]. In other words, environmental injustice is resulted from lack of fair distribution of resources, recognition, participation, and capabilities. In this paper, we argue that the problems of land grabbing would have negative impacts on overall human development in Ethiopia. 


\section{Discussion and Critical Remarks}

According to Lorenzo Cotula and others, the notion land grabbing is defined as "large-scale land acquisitions (LSLAs)" which in turn is broadly defined as "acquisitions (whether purchases, leases or other) of land areas over 1,000 ha" [8]. It refers to the purchase or lease of vast hectors of land for different purposes such as food securities in a ways that domestic governments, Transnational companies, foreign governments, and private investors from developing and developed countries have tried to own large tracts of land in developing countries in order to produce crops. Likewise, Tinyade Kachika contends that:

Some are diplomatically calling the phenomenon "commercial pressures on land," "(foreign) investment in land," and "large-scale land acquisitions." However, some are out rightly naming it "land grabbing." Land acquisition has been defined broadly to include not only the purchase of ownership rights, but also the acquisition of user rights-i.e. through leases or concessions, whether for a short or a long term. On the other hand, land grabbing has been defined as taking possession of, and or controlling a scale of land for commercial and industrial agricultural production that is disproportionate in size in comparison to the average land holding in the region [9].

Kachika further stated that the notion land grabbing or large scale land acquisition in Africa has begun as a response to global food crises from 2007-2008 though scrambling for African land is not a new phenomenon. In response to the crises, many developing countries were opened to foreign direct investment (FDI) especially in agribusiness and tourism. As a result, African fertile land is offered to investors at very low prices. But the new scramble for Africa is based on the common interest of both foreign governments and host governments unlike the old scramble for Africa that used military invention to conquer African land and its natural resources.

As in many African countries, the phenomenon of large scale land acquisition has expanded drastically in Ethiopia [5]. For instance, report has made critical assessment of the issue of commercial land investment in Ethiopia [10]. According to this report the land investment has increased food insecurity in the country in a way that all the harvest will be exported to abroad without achieving any significant gain from it. Moreover, local communities are displaced from their farm land without getting proper compensation. There was no meaningful environmental impact assessment [10].

According to Mengistu Adugna there are some factors that encouraged the LSLAs [5]. These include food security concerns, biofuels and financial incentive. He claims that the case of food security is related with sky rocketing price of 2007 and 2008 at the global level as a result of limited availability of water and arable land. To solve this problem, the food importing nations started to look for the easily accessible arable land in developing nations. In response to biofeuls crises in 2008 and 2009, many countries are interested in biofeul investments for the reason of the diminishing supplies of non-renewable resources in different parts of the world. To solve the given problem, many countries are interested in obtaining land for the production of agrofuel or biofuel crops such as jatropha, palm oil, maize and soya, since these renewable crops are very important for fuel production.

The other factor that opened the way for LSLAs is financial incentive. It implies Cotula claims, market instability that resulted from rising agricultural community prices at an international level and attracted investors to invest on farmland. All these factors are opened the way for LSLAs in one way or the other. And this land acquisition will have a negative impact on the life of African societies claim that there are different factors that undermine the position of local peoples as a result of LSLAs [5]. Among others, these factors include, lack of transparency and of checks and balances in contract negotiations that open the way for corruption and restrict the public interest; insecure use rights on state-owned land; inaccessible registration procedures; legislative gaps; and lack of fair compensation for the small scale farmers. All these factors will end-up in local people losing access to the resources on which they depend for their food security and livelihoods. Rather than solving the local peoples' problem, LSLAs "can undermine the well being of local communities, both in terms of land rights as well as access to food" The African governments are engaged in fixing eviction policies that are essentially grabbing land from rural minorities [9].

According to the Oakland Institute in many African countries (like Ethiopia, Serra Leone and Liberia), there is land market (land grabbing) that transferred the land to foreign investors in the name of improving the countries investment policies [6]. International Financial Corporation (IFC) and the Foreign Investment Advisory Service (FIAS) have provided technical assistance and advisory services to lease their land. The question is 'where is this land coming from?' Many studies explored that most of the land that is given to the concerned investors is already occupied and used by millions of local farmers. In connection to this, Kachika claims that "the land for large scale fuel production must come from somewhere-whether from small farmers' land, communal land, or conservation areas. There is no unoccupied in any of parts our countries, so communities will inevitably be displaced and denied of their land territories and natural resources"[9]. As a result, many local African communities have suffered a lot as a result of land market as this land is the source of subsistence for these poor communities. And it provides them with food, medicine, construction materials, fuel and other purposes. Furthermore, this action has played a significant role in undermining African development in the name of improving the "investment climates" and "business enabling environments" of developing countries [mentioned under 4]. In addition, Dessaleng Rahmato also writes:

According to international media reports, many market analysts are of the opinion that volatility in the world food trade will continue to drive up commodity prices and to cause periodic global shortages for many years to come. There is thus a strong food security element in the on-going global 
land grab phenomenon. At the same time, the rush for land in Africa by investors from the Gulf countries, India, China and South Korea, has also been driven by the assumption that land is abundant in the continent, land rents and labor costs are low, and there are few regulatory roadblocks restricting production and export [11].

Rahmato argues that many countries in Africa including Ethiopia have given millions of hectares of farmland to investors in the name of large-scale investment, and they believe this will provide opportunities for rapid agrarian development that can play significant role in tackling rural poverty in the continent. In connection with this, he states, the land is owned by the government in Ethiopia. So, government authorities can give away land to investors without consulting farmers and making environmental impact assessment [11]. Thus, this problem is observable in many African countries. Understanding and looking for solutions for such problems would be significant to provide a better protection for Africans since there are many possible mechanisms that might help us to alleviate or reduce the given problems. One is organizing farmers in collaboration with government to let it be investment that begins from within or farmers have share from mechanized agriculture or companies or whatever things that can improve the quality of their life.

The notion of large scale land investment is somehow understood as a controversial phenomenon. Different researchers try to find out whether or not this kind of farmland investments can help to the recipient country to develop. In this case, proponents of large scale land investment argued that "this is a new type of development opportunity where foreign direct investments can increase the gross domestic product and create a win-win situation for all parties; the foreign company, the domestic government and local societies" [12]. Further, the proponents of large scale land investment claim that it will have a positive role in improving societal life like creating job opportunity, ensuring food security, enhancing government revenues etc.

In contrast, "others claim this to be a type of imperialism where poor countries are exhausted of their natural resources" [12]. Although large scale land investment could create development opportunities for developing countries, inversely it can play a great role in the deterioration of their culture, livelihood, human dignity and wellbeing in general. We will later show the negative impacts of large scale land acquisition LSLA in developing countries including Ethiopia. Large scale land acquisition will have negative impacts on African different social affairs like undermining culture, religion, livelihood, dignity, wellbeing etc.

The Human Rights Watch HRW report in 2011 mentioned that since 2008 Ethiopian government has leased out at least 3.6 million hectares of land to both foreign and local investors [13]. And these hectares of land are equal with the size of Netherlands. Further, this report states that 2.1 million hectares of fertile land were reserved in the federal government's land bank for the commercial investment purpose. According to this report, Gambella region in the south-west of the country is one of the most vulnerable areas for the land investment deals. In this region, approximately 70,000 people were relocated at the end of 2011 [13].

According to Ethiopian government, the plan of relocating people is voluntary and it aims to provide them basic socioeconomic infrastructure that will have significant contribution in securing their livelihoods [13]. But the Human Rights Watch report claims that there is no meaningful consultation and payment of compensation for the relocated communities [5]. In connection to this, The Oakland Institute states:

No single land investment has garnered as much media attention as that of Karuturi. Reports surfaced in 2008 that the Indian giant, already active in Ethiopia's floriculture industry, had acquired 300,000 ha for a 99 year lease in Gambella (3,000 $\mathrm{km}^{2} / 1,150$ miles 2) for food production. Rents for this massive area were reported to be as low as 1520 birr per ha (USD 1-1.25). This was one of the first major foreign land investments in Ethiopia, and was negotiated between Karuturi and the Gambella Regional Council, without the involvement of the federal government [14].

This phenomenon has dragged people from their original place. This is antihuman rights deed in the name of reducing food insecurity in Ethiopia. Rahmato claims that the Karuturi Indian conglomerate company has been also given 11,000 hectares of fertile land in Bakoworeda in Oromia region [9]. Also, he claims that a number of hectares of lands in Ethiopia were offered to investors for different purposes. For instance, he claims, one of the richest men in the Middle East, controls, through his numerous group of companies established in Ethiopia, extensive agricultural land in various Regions. These lands include a large tea estate, over seven large ranches for raising livestock and processing dairy and poultry products both for the home and export market, and extensive possessions for growing food crops. His newly established mult-purpose firm, Horizon Ethiopia Investments, has submitted a request for 100,000 hectares of land in Gambella to grow palm oil and other biofuel crops, and has recently acquired 85,000 hectares of land in Bench Majji Zone in southern nations, nationalities, and peoples (SNNP) to establish a rubber plantation [14].

The Elfora Agro-Industry is the largest livestock company in Ethiopia and it is located in Borana zone in Oromia [9]. The report states that the company nowadays has the capacity to produce 65,000 head of cattle and 400,000 head of sheep and goats per year. And it supplies these products to the largest hotels, enterprises, and the military camp in the country; and to the Gulf States. Further, the report claims that as a result of the Elfora Agro-Industries, the Borana local pastoralists have been evicted both from their lands and livelihoods as they have lost access to their dry-season grazing land since the company started operations there [14].

Is land grabbing really important for development as it is propagated by the local governments?

Or do the policies of land investment, in Africa or Ethiopia, fit with what is happening on the ground in local communities? Rahmato argues that the major objectives of 


\section{LSLA in Ethiopia or Africa include:}

a) produce export crops and hence increase the country's foreign earnings; it is also expected to expand production of crops needed for agro-industry such as cotton and sugar cane; b) create employment opportunities in the localities concerned; c) benefit local communities through the construction of infrastructure and social assets such as health posts, schools, access to clean water; d) provide the opportunity for technology transfer; and e) promote energy security [14].

On the contrary, he claims, LSLA intensified poverty in local communities by displacing societies from their land, which is the backbone of their survival, and there were no feasible technology transfer, meaningful compensation, adequate food, job opportunity, agricultural support, and health and education facilities for evicted people. In addition, the arbitrary eviction from one's own land has serious implications to the violation of the right to development and the right to free from poverty [5] The Oakland Institute also identified the large discrepancies between publicly stated positions, laws, policies and procedures and what is actually happening on the ground concerning the issue of land grabbing in Ethiopia [5]. The Ethiopian government argues that "for all land deals consultation is being carried out, no farmers are displaced and the land being granted is unused"[5]. In contrast, the report debunked that the Oakland Institute team did not find a single evidence of community consultation and every investment site it visited involved the loss of local farmland. Further, OI team claims that every investment area manifests certain sort of sociocultural/ecological values associated with it prior to land investment [5].

According to the UN's 2007 report on Ethiopia, the issue of land grabbing in the country is also the concern of human rights violation, as it has placed the minority communities due to factors like resettlement, conflict, assimilation, cultural dilution, environmental factors and loss of land [5]. As a result of this, the report claims that land grabbing is also serious human rights violation that in turn negatively affects the overall development of the country. The Oakland Institute also states, "African land grabs are nothing new, but the scale at which they are occurring is unprecedented. We are at the crossroads" [14]. This implies that African governments are not transparent rather they are corruptor and this in turn is enable the poorest populations more vulnerable. Jan Egeland, who is the HRW's Europe director, claims that "the Ethiopian government's villagisation program is not improving access to services for Gambella's indigenous people but is instead undermining their livelihoods and food security" [mentioned under 8]. Egeland claims that the Ethiopian government has to suspend the program until it consults people and compensate for their lost lands; and proper infrastructure is in place for the evicted people [14].

In short, land grabbing will have negative impacts on development because of different reasons. These reasons include: lack of meaningful consultation, low quality of compensation, defective contracts, monopoly of water resources, lack of adequate social services etcetera after they evicted from their land. The aim of land investment in Ethiopia is to shift from small-scale to large-scale farming that hasbeen dominated by foreign investors. But LSLA in Ethiopia will "pose a serious threat to the long-term sustainability of the rural economy, the livelihoods of peasants and pastoralists, and to the goals of achieving food security" [14]. And the LSLA will steadily marginalize the small-scale farmers and bring unequal and antagonisticsocialclasses. In other words, it creates a wide gap between the haves and have-nots in rural communities (those privileged by the program and those disadvantaged by it) [14]. Here the question is "what needs to happen to reverse this dangerous trend?" In response to the LSLA, the News Embargoed Dec. 6, 2011, report entitled "Understanding Land Investment Deals in Africa" states that:

There is still a chance to stop the momentum of this dangerous trend by demanding responsible policy shifts in rich countries and supporting the ability of African farmers to protect themselves from these land grabs. Players such as the World Bank and development agencies such as USAID, the Commonwealth Development Corporation and NORFUND must recognize the harmful impact of their current approach to development [13].

The report claims that developed countries and various international organizations such as the World Bank, USAID, the Commonwealth Development Corporation and NORFUND are responsible to solve the problems of land grabbing in developing countries, including Africa, by changing their policies regarding the given issue.

The very concept of environmental justice is one of the prominent issues in the history of environmental ethics. According to David Schlosberg, the most often and popular meaning of environmental justice is fair distribution of environmental goods and bads to all humans [1]. The integration of Addis Ababa, the capital city of Ethiopia, with the surrounding area is one form of environmental injustice in Ethiopia. According to Amnesty International report, the 'Addis Ababa-Finfinne ${ }^{1}$ Integrated Development Plan' ('Master Plan') or shortly 'Integrated Master Plan' that aims to expand the capital, Addis Ababa, into Oromia regional territory is another example of land grabbing or forced eviction in the country [15]. Amnesty International report claims that the 'Master Plan' began in April and May 2014. And it was proposed to integrate Addis Ababa with its surroundings in Oromia regional state in the name of 'Integrated Development.' In contrast to the Ethiopian government's ambitious plan, the peaceful protests broke out across Oromia against a proposed 'Integrated Master Plan' for the fear that it will lead to the eviction of thousands of farmers and other people from their lands and settlements. Though the protest was peaceful, the government responded to it with unnecessary and excessive force like firing live ammunition on peaceful protestors and beating hundreds of peaceful protestors at different places in the region. The

${ }^{1}$ Finfinne is another name of Addis Ababa as the Oromo call it. 
report also states that the protests resulted in deaths, injuries and imprisonment of many people all over the state.

Ethiopia Human Rights Project (EHRP) report indicates that the 'Master Plan' aimed to occupy 1.1 million hectares of land that is approximately twenty fold the current size of Addis Ababa and its implementation will result in the eviction of millions of farmers and families from their land. The report also shows that the 2014 protests against the Master plan was dubbed as the first protests that mainly involved students of Oromia regional state in April/May/June 2014. The report claims that the protests erupted again beginning from mid November 2015 and continued for the consecutive 100 days. Unlike the first protests that mainly were undertaken by the students in the region, this phase of the protests is broader than the first one, as it encompasses all segments of the communities across the region from students to teachers, government employees to farmers, town dwellers to rural dwellers, doctors to street children, Oromo nations living in the country to diasporas etc [16].

The Oromo peoples' protests that began in response to Master Plan were not confined to the questions of the Plan. Rather it goes beyond this and included the question of democracy and human rights [16]. Boldly perceivable ruling party's growing trend of repression and human rights violation in the region are the major components of the protests. That is why the protests have continued even after the regime announced that the plan would not be implemented [16]. The main reason for the protests as the Oromo Federalist Congress (OFC), the leading opposition political party in Ethiopia, made public in April 2014 is:

The fact that the new development plan aimed to enlarge the size of Addis Ababa city will have multidimensional problems beyond taking lands from the surrounding areas of Oromia State. It will affect the right to education of the population with their own lingua franca, it will affect their culture and it may have a gerrymandering effect [16].

This quotation implies that the moment "Integrated Master Plan" is implemented; it will have negative impacts on Oromo communities' life situations like affecting the right to education in their own language, history, identity and etcetera that will in turn end up even in laming their overall development concerns in one way or another.

Henok Gabissa, the President of Oromo Study Association (OSA), forwarded certain ideas during the OSA Symposium held in Washington-DC on January 16, 2016. Henok argues that though the Addis Ababa Master Plan, as propagated by Ethiopian regime, plays in the name of "Integrated development", it has another hidden agenda such as dividing the Oromo land in to two: west and east. This hidden strategy, if succeeded, will significantly distort the physical and cultural oneness of Oromo nation. The other hidden agenda is political scheme that aimed to systematically transfer land from the hands of poor farmers to others. In other words, the plan aimed to dislocate, dispossess and disfranchise the Oromo people who live in Addis Ababa and its surrounding without significant compensation and consultation with them. He claims that when the plan is implemented, it will remove all 6 million Oromo people from 17 surrounding towns and rural districts. As a result of this situation, the language and social fabric; identity and the very existence of Oromo will be put in the complete political vacuum. To substantiate this he asks, "Why wouldn't the government in power give access to the Oromo investors?" If so, the development is lead under the ownership of the Oromo themselves. But the government does not give chance for Oromo investors rather it evicts the Oromo people from their lands [17].

Also, Henok states that the plan violates the Oromo right to sustainable development and the right to live in the clean and healthy environment. And it violates economic rights such as property and food they produce on their land; it violates freedom of information and opinion; and the right to education. Therefore, Henok claims that the plan is an anti-thesis to development and causes anti-existential threat to the economic security and property rights of the Oromo people that in turn is an anti-thesis to urbanization and urban growth [17].

I agree with his view and I argue that there is no reason for the Oromo community to deny development that will positively change their life. There is no society that denies genuine development. But the case of "Integrated Development Master Plan" is different from genuine development project. More clearly, the Ethiopian government is telling the Oromo people about the positive aspect of the master plan. It doesn't mean that the Ethiopian government should not interfere in Oromo case. But they can interfere by consulting them about the issue in a more transparent and logical way, unless, the issue is like let me know more about you than you know yourself, or let me decide more closely on your livelihoods than you decide over yourself. The regime didn't even understand the moral value that the Oromo society has regarding their land.

For the Oromo people land is considered as sacred, venerated and respected form of property. So, what kind of development government would think to bring about by evicting the people from their land? I think that rather than calling it development, backwardness is proper term to be used in this situation.

As Ethiopian Human Rights Report noted, it is very serious instance of the human rights violations penetrated by the government security forces in response to the protests in Oromia region [16]. The report claims that the protests were peaceful and legal. Nevertheless, the Ethiopian government argues that the protests were violent. The Ethiopian government labeled the protests as an act of terrorism that needs violent reaction. As a result, it used excessive force, heavy weapons like helicopters and tanks that caused the death of and an injury to the children from the age of eight to elderly aged seventy eight [16].

\section{Conclusion}

The concern of land grabbing has got the attention of philosophers and scientists. As it had been discussed in detail, local communities have faced various problems resulted from 
land grabbing in Ethiopia. Putting other way, land grabbing has negative impact on sustainable human development in Ethiopia since it displaces local communities from their land without getting proper compensation from the concerned bodies. As a result, we tried to discuss the ideas of many thinkers to realize the validity of negative nexus between land grabbing and development in Ethiopia. The problems of land grabbing is reality in many parts of Ethiopia like Gambella, Oromia and Benishangul-Gumuz regions. For instance, Indian Conglomerate Karuturi Company had acquired so many hectares of land by displacing local communities without paying proper compensation for the local societies in the above mentioned regions of Ethiopia. The Elfora Agro-Industries owner has also evicted poor societies from their land without proper compensation. We also discussed the integration of Addis Ababa, the capital city of Ethiopia, with the surrounding area as one form of land grabbing which impose negative impacts on the genuine development of local communities in Ethiopia. As a result, we suggest that inspiring marginalized communities to participate in environmental decision making is very important issue.

What we want to recommend realizing environmental justice and proper development in Ethiopia is meaningful involvement and active participation of government at different levels---local, national and global. Moreover, broad public participation and access to information, meaningful involvement and active participation of judiciaries, academicians, and researchers are also other components which enable us to realize sound environmental justice and development in Africa. In addition, all major groups: women, children and youth, indigenous peoples, non-governmental organizations, local authorities, workers and trade unions, business and industry, the scientific and technological community, and farmers, as well as other stakeholders, including local communities, volunteer groups and foundations, migrants and families as well as older persons and persons with disabilities are significant components in realizing environmental justice and development. Furthermore, all concerned people are responsible to influence the government through different means in order to realize the relationship between environmental justice and development in Ethiopia.

\section{References}

[1] Schlosberg, David. (2007) Defining Environmental Justice: Theories, Movements, and Sen, Nature. New York and Oxford: Oxford University Press.

[2] Shrader- Frechette, Kristin (2002) Environmental Justice:
Creating Equality, Reclaiming Democracy. Oxford: Oxford University Press.

[3] Pellow, David N. (2007). Resisting Global Toxics: Transnational Movements for Environmental Justice. Cambridge, Massachusetts and London: The MIT Press.

[4] Girma, Henok (2014). Environmental Injustice, Human Rights and Democracy in Africa. Addis Ababa University.

[5] Adugna, Mengistu (2015) Environmental Injustice, Human Rights Violation and Development in Africa. Addis Ababa University.

[6] The Oakland Institute (2010) (Mis) investment in Agriculture: The Role of the International Finance Corporation In Global Land Grabs. Oakland: USA.

[7] Rahmato, Dessalegn. (2014) The Perils of Development from above: Land Deals in Ethiopia. V.12 Taylor and Francis Group.

[8] Cotula, Lorenzo, Sorja, Vermeulen, Rebeca, Leonard, and James, Keeley. (2009) Land Grab or Development Opportunity? Agricultural Investment and International Land Deals In Africa. London/Rome: IIED/FAO/IFAD.

[9] Kachika, Tinyade. (2010) Land Grabbing in Africa: A Review of the Impacts and the Possible Policy Responses. (Unpublished)

[10] The Oakland Institute (2011a). Understanding Land Investment Deals in Africa: Country report: Ethiopia. Oakland: USA.

[11] Rahmato, Dessalegn. (2011) Landto Investors: Large-Scale Land Transfers in Ethiopia. FSS Discussion Paper, Forum for Social Studies, Addis Ababa.

[12] Riedel, Karolina (2011) "Land Grabbing in Ethiopia-Welfare or Farewell: Is it a Story Painted In Black and White?", MA thesis (Sweden). University of Gothenburg.

[13] The Oakland Institute (2011b). Understanding Land Investment Deals in Africa: FAQs on How Land Grabs Contribute to Hunger and Conflict. Oakland: USA.

[14] Mahaprashasta, J. Ashirwad. (2012) World Affairs: Recolonising Afria: Ethiopia witnesses large- scale forcible displacement of villagers in what has become the norm in the past decade in Africa. U.S. Frontline.

[15] Amnesty International. (2014) "Because I am Oromo: Sweeping Repression in the Oromia Region of Ethiopia." London: United Kingdom.

[16] Ethiopia Human Rights Project. (2016) "Oromo Protests: 100 Days of Public Protests.” Addis Ababa. Ethiopia.

[17] Henok, Gabissa. (2016) "Master Plan and the Oromo Protests. OSA Symposium, Washington DC." (www.oromostudies.org). 